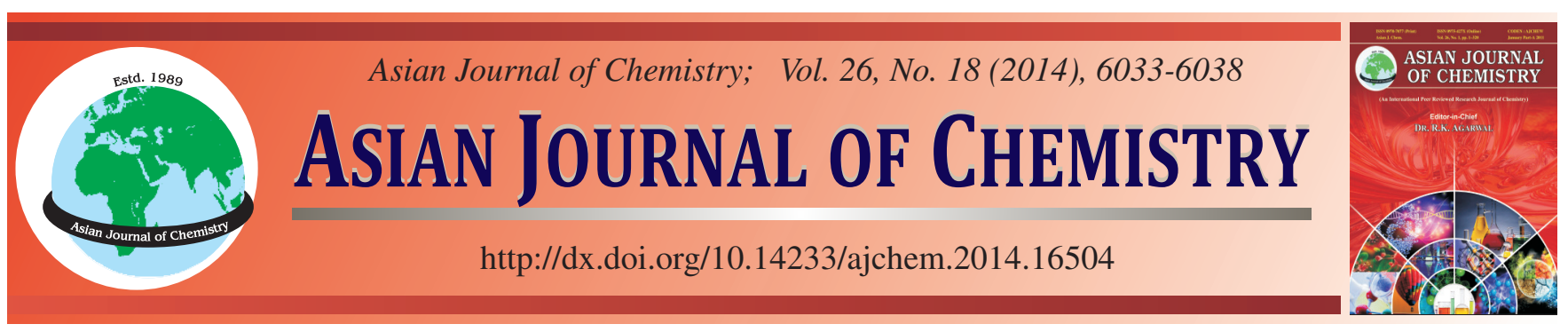

\title{
Neutron Permeation Properties and Characterization of Synthesized Non-Hydrated Magnesium Borate Minerals
}

Azmi Seyhun Kipcak ${ }^{1}$, Emek Moroydor Derun ${ }^{1, *}$, Fatma Tugce Senberber ${ }^{1}$,

Ozgul Dere Ozdemir ${ }^{1}$, Derra Yilmaz Baysoy ${ }^{2}$ and Sabriye Piskin ${ }^{1}$

${ }^{1}$ Department of Chemical Engineering, Yildiz Technical University, Istanbul, Turkey

${ }^{2}$ Department of Physics, Mimar Sinan Fine Arts University, Istanbul, Turkey

*Corresponding author: Fax: +90 212 3834725; Tel: +90 212 3834776; E-mail: moroydor@ gmail.com

\begin{abstract}
Magnesium borates are excellent materials due to their thermal and mechanical properties. In this study, the thermal (solid-state) synthesis was used for the production of non-hydrated magnesium borate minerals. In the X-ray diffraction results of thermal synthesis, Kotoite (K) "01-0751807, $\mathrm{Mg}_{3}\left(\mathrm{BO}_{3}\right)_{2}$ ", Suanite $(\mathrm{S})$ "01-086-0531, $\mathrm{Mg}_{2}\left(\mathrm{~B}_{2} \mathrm{O}_{5}\right)$ " and $\left(\mathrm{MgB}^{1}\right)$ "00-031-0787, $\mathrm{MgB}_{4} \mathrm{O}_{7}$ " and $\left(\mathrm{MgB}^{2}\right)$ "01-073-2232, $\mathrm{Mg}_{2} \mathrm{~B}_{2} \mathrm{O}_{5}$ " were produced. Higher XRD scores were seen at the molar ratios of 3:2 and 1:1. Materials, XRD scores increased with increasing temperature and time. Molar ratios, reaction temperature and time for the best crystal magnesium borate materials production were determined as 3:2-1:1, 1000 ${ }^{\circ} \mathrm{C}$ and $240 \mathrm{~min}$. Products at the highest XRD scores were subjected to neutron permeability analyses. Neutron permeability decreased with increasing thickness of the material. Increase of molar ratio of the raw materials contributed to the neutron permeability of product. The lowest values of total macroscopic cross section and neutron permeability have been found for $3: 2$ of $\mathrm{MgO}: \mathrm{H}_{3} \mathrm{BO}_{3}$ ratio and $1.25 \mathrm{~cm}$ thickness.
\end{abstract}

Keywords: Magnesium borate, Microstructure, Neutron capture cross section, Radiation shielding, Solid state synthesis, Spectroscopy.

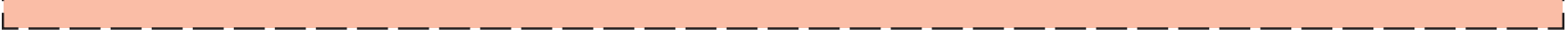

\section{INTRODUCTION}

Boron minerals, which are abundantly present in Turkey holds about $72 \%$ of their reserves with the largest share, have been investigated for decades all over the world ${ }^{1}$. Metal borates, which are a member of notable ceramic materials, are useful additives in industry due to their features such as great mechanical properties, good chemical resistance and low density, as well as low thermal expansion coefficient. Magnesium borate minerals, which are a sub-class of metal borate minerals, have excellent potential in the development of thermo-luminescence phosphor materials, detergents composition, energy conversion and storage systems, production of superconducting materials, whisker-reinforced composites and reducing friction additives. At the same time, they can be used in the production of-materials against-neutron and $\gamma$-radiation due to their high content of boron ${ }^{2-5}$.

Production of non-hydrated magnesium borates has been an interesting topic for a decade. Dosler et $a l^{2}{ }^{2}$ synthesized single-phase $\mathrm{Mg}_{3} \mathrm{~B}_{2} \mathrm{O}_{6}$ and $\mathrm{Mg}_{2} \mathrm{~B}_{2} \mathrm{O}_{5}$ ceramics by solid-state reaction techniques by using the raw materials of $\mathrm{MgO}$ and $\mathrm{B}_{2} \mathrm{O}_{3}$. At the end of the experiments, it was seen that $\mathrm{Mg}_{2} \mathrm{~B}_{2} \mathrm{O}_{5}$ and $\mathrm{Mg}_{3} \mathrm{~B}_{2} \mathrm{O}_{6}$ were formed at temperatures ranging between 1250-1280 ${ }^{\circ} \mathrm{C}$, respectively ${ }^{2}$. In another study on thermal synthesis, powder of $\mathrm{Mg}\left(\mathrm{BO}_{2}\right)_{2} \cdot 2 \mathrm{H}_{2} \mathrm{O}$ was used as the raw material for the synthesis of monoclinic $\mathrm{Mg}_{2} \mathrm{~B}_{2} \mathrm{O}_{5}$ between 1000 and $1300{ }^{\circ} \mathrm{C}$ with a heating rate of $10^{\circ} \mathrm{C} / \mathrm{min}$ under the pressure of $0.1 \mathrm{~Pa}^{4}$. Zhihong and Mancheng ${ }^{6}$ prepared $\mathrm{Mg}_{3} \mathrm{~B}_{2} \mathrm{O}_{6}$ nanobelts with the mixture of $\mathrm{B}$ and $\mathrm{MgO}$ at the mole ratio of $1: 1$, under the mixture of $\mathrm{Ar} / \mathrm{H}_{2} \mathrm{O}$ atmosphere. The mixture of $\mathrm{B}$ and $\mathrm{MgO}$ powders was heated to $1100{ }^{\circ} \mathrm{C}$ and held at this temperature for $1.5 \mathrm{~h}$. Single-crystalline magnesium borate $\mathrm{Mg}_{2} \mathrm{~B}_{2} \mathrm{O}_{5}$ nano-rods, were obtained via a simple route that depended on the sintering process of mixed powders containing $\mathrm{Mg}(\mathrm{OH})_{2}$ and $\mathrm{H}_{3} \mathrm{BO}_{3}$ at the temperature of $900{ }^{\circ} \mathrm{C}$ for $3 \mathrm{~h}$ and then milling process was applied. The nanorods had the lengths up to a few micrometers ${ }^{7}$. Kipcak et al. ${ }^{8}$ sintered the mixture of magnesium oxide and periclase at $800{ }^{\circ} \mathrm{C}$ and this showed that transformation began but temperature was insufficient for full conversion process.

All previous studies focus on the use of boron as an additive material for neutron shielding. Korkut et al. ${ }^{9}$ studied the fast neutron shielding properties of $\mathrm{MgB}^{2}, \mathrm{NaBH}_{4}$ and $\mathrm{KBH}_{4}{ }^{9}$. Buiyan and $\mathrm{Ahmet}^{10}$ synthesized a shield material, called polyboron, by adding boron into a matrix of polyethylene. Gwaily et $a l .{ }^{11}$ used boron carbide and natural rubber (40 HAF/NR) to create-thermal neutron radiation shielding. Their experimental results showed that the permeability decreased linearly 
as the thickness of the sample increased. In the study of Adib and Kilany, as a thermal neutron filter, element bismuth instead of lead was investigated ${ }^{12}$. Singh et al. ${ }^{13}$ produced $\mathrm{PbO}-\mathrm{B}_{2} \mathrm{O}_{3}$ and $\mathrm{Bi}_{2} \mathrm{O}_{3}-\mathrm{PbO}-\mathrm{B}_{2} \mathrm{O}_{3}$ shield materials at different compositions. Derun and Kipcak ${ }^{14}$ studied the neutron absorption and transmission properties of sodium and calcium borates. According to their experiments, specifically kurnakovite was determined to yield the lowest neutron permeability value and therefore, the use of these materials for neutron shielding would be suitable. There haven't been any papers regarding the neutron permeability of magnesium borate minerals.

As it is seen in the literature, non-hydrated magnesium borates were produced at higher temperatures than $900{ }^{\circ} \mathrm{C}$ and all these studies needed the milling process for a long time. Amorphous products were obtained or sufficient conversions were not achieved. In these studies, temperature effect was studied. However, the effects of parameters such as reaction time and molar ratio of reactants were not clearly examined. Although the feature of neutron and $\gamma$-radiation absorbance of boron is known in literature. Compared with the previous studies, the novelty of this paper is investigating the neutron permeation of magnesium borate minerals. In this study, it is aimed to synthesize products at higher XRD scores. The effect of magnesium borate minerals' XRD scores on neutron permeability was also examined.

\section{EXPERIMENTAL}

Preparation and identification analysis of raw materials: Magnesium oxide and boric acid were supplied form Merck Chemicals and Kirka Boron Management Plant in Eskisehir, respectively, were selected as raw materials. Magnesium oxide was used without pretreatment and boric acid was crushed, grinded and sieved under 75 microns. Identification analysis of components was made by Philips PANanalytical X-Ray Diffraction. X-rays were produced from a $\mathrm{CuK}_{\alpha}$ tube at $45 \mathrm{kV}$ and $40 \mathrm{~mA}$.

Reaction parameters of production process: To investigate the effect of molar ratio of raw materials, magnesium oxide and boric acid were mixed and pressed with different molar ratios of $\mathrm{MgO} / \mathrm{H}_{3} \mathrm{BO}_{3}$. Manfred OL57 was used for the pressing operation. These ratios were selected as 2:1, 3:2, 1:1 and 1:2. To search the effect of reaction temperature, calcination temperatures were determined as 900 and $1000{ }^{\circ} \mathrm{C}$. In the synthesis process, ceramic crucibles were used with a heating rate of $10{ }^{\circ} \mathrm{C} / \mathrm{min}$ at high temperature furnace of Protherm MOS180/4. To determine the effect of reaction time, calcination processes were applied for 60 and $240 \mathrm{~min}$ at the determined temperatures. The final products were milled in an agate mortar.

Characterization of synthesized minerals: After the synthesis of non-hydrated magnesium borates, X-rays were produced from a $\mathrm{CuK} \alpha$ tube at $45 \mathrm{kV}$ and $40 \mathrm{~mA}$ for XRD analyses.

For the characterization analysis of products, Perkin Elmer Brand FT-IR with Universal Attenuated Total Reflectance (ATR) sampling accessory-Diamond/ZnSe crystal was used. Measurement range was selected as $1800-650 \mathrm{~cm}^{-1}$. After FTIR analysis, Perkin Elmer Brand Raman spectrometer was used for further analysis. For Raman spectroscopy, the exposure time was set to $4 \mathrm{sec}$ and number of exposures was set to 4 . Measurement range was selected as $1800-250 \mathrm{~cm}^{-1}$ and data interval was selected as $2 \mathrm{~cm}^{-1}$. In addition to characterization analyses, SEM analysis was applied for the surface morphology. CamScan Apollo 300 field-emission SEM was used and experiments were conducted at $20 \mathrm{kV}$. Detector used was back scattering electron (BEI) and magnification was set to $5000 \mathrm{x}$.

After the solid-state synthesis, boron oxide $\left(\mathrm{B}_{2} \mathrm{O}_{3}\right)$ contents of the minerals were determined with the titration method. $1 \mathrm{~g}$ of each product was dissolved in $3 \mathrm{~mL}$ of $37 \% \mathrm{HCl}$ and titrated with $\mathrm{NaOH}$. Pure $\mathrm{H}_{3} \mathrm{BO}_{3}$ at the same conditions was used as the reference material.

Neutron permeation of synthesized minerals: Synthesized minerals $(10,15$ and $25 \mathrm{~g})$ were mixed with $10 \%$ Wax ${ }^{\circledR}$ by weight and then pelleted in three different thicknesses which were measured as $0.55,0.75$ and $1.25 \mathrm{~cm}$. Neutron permeation experiments were carried out by Am-Be neutron flux with the activity of $74 \mathrm{GBq}$ from a source located within Howitzer the Çekmece Nuclear Research and Training Center, Turkey. Fast neutrons, which produced by a neutron source, have the average energy value of $4.5 \mathrm{MeV}$ and maximum energy level of 12 $\mathrm{MeV} . \mathrm{BF}_{3}$ neutron detector with diameter of $2.54 \mathrm{~cm}$ and length of $28 \mathrm{~cm}$ was used during the experiments. Since the minerals were placed at the exit of the source beam collimation component was not used. Neutron permeability experimental setup is schematized in Fig. 1. The three pellets, with different thicknesses, were exposed to neutrons in the Howitzer device for $5 \mathrm{~min}$ and three parallel experiments were conducted.

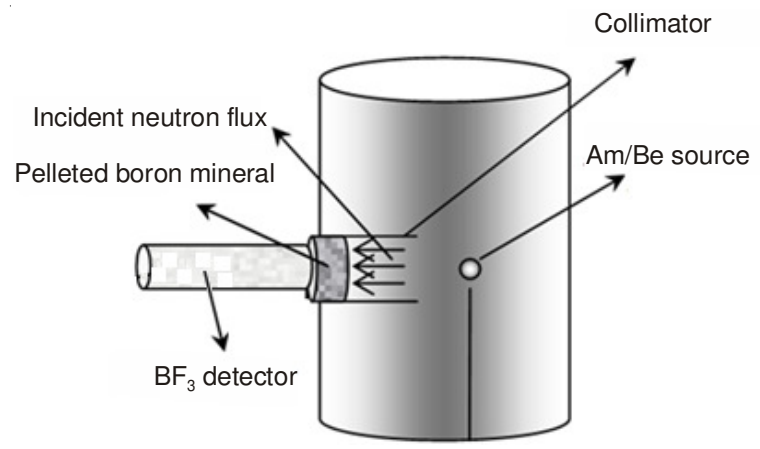

Fig. 1. Schematic diagram of neutron permeability experimental setup

The neutron permeability is determined from $\mathrm{I} / \mathrm{I}_{0}$ and $\mathrm{x}$, where $\mathrm{I}$ and $\mathrm{I}_{0}$ are the transmitted and incident neutron fluxes, respectively and $\mathrm{x}$ is the thickness of the mineral ${ }^{15}$. To discuss about neutron shielding properties of the synthesized minerals, values of total macroscopic cross section $\left(\Sigma_{\mathrm{t}}\right)$ can be calculated from Beer-Lambert Law in equation:

$$
\frac{\mathrm{I}}{\mathrm{I}_{0}}=\mathrm{e}^{-\Sigma_{\mathrm{t}} \mathrm{x}}
$$

Total macroscopic cross sections were calculated for each thickness and their average values were calculated.

\section{RESULTS AND DISCUSSION}

Characterization results of magnesium oxide and boric acid: XRD patterns of magnesium oxide and boric acid are 
shown in Fig. 2. It is known that boric acid loses its water at higher temperatures and turn into boron oxide $\left(\mathrm{B}_{2} \mathrm{O}_{3}\right)$. According to $\mathrm{XRD}$ results, raw materials were found with refer ence codes and of scores of "01-087-0651" and 78 for $\mathrm{MgO}$ and "01-073-2158" and 62 for $\mathrm{H}_{3} \mathrm{BO}_{3}$. After boric acid was heated, it transformed to boron oxide which has reference code and score of "00-006-0297" and 42, respectively.
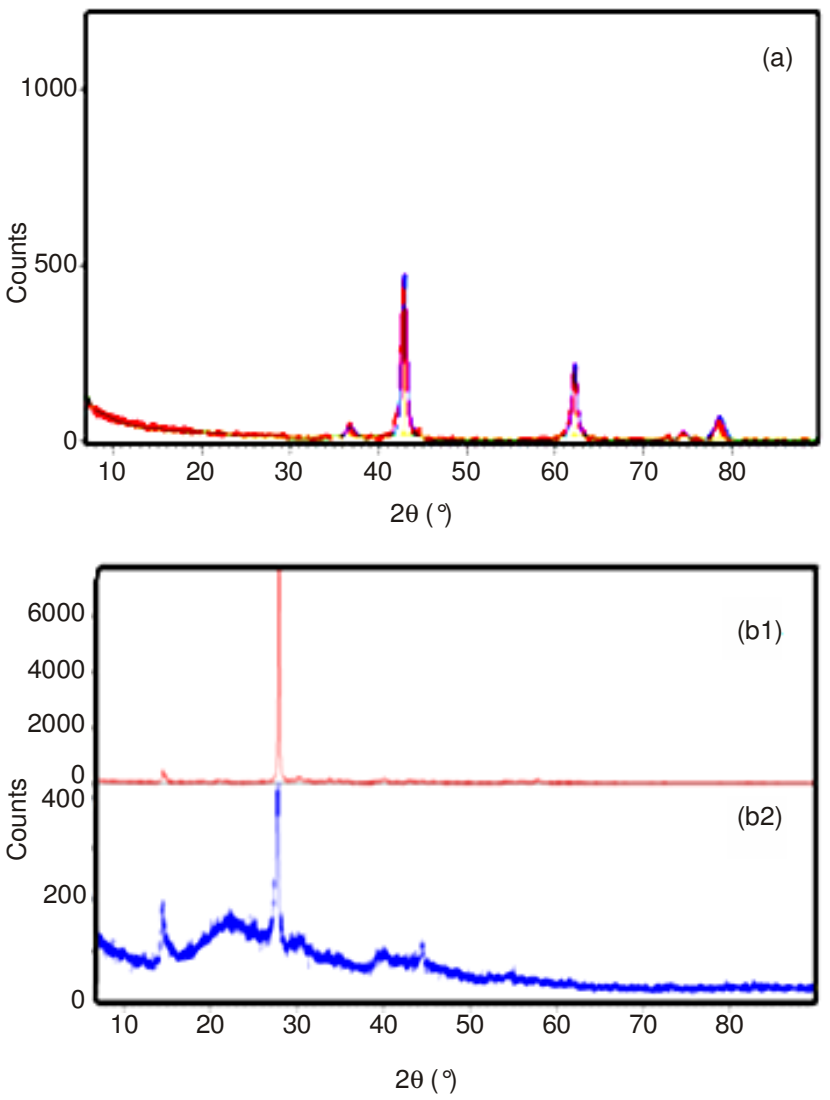

Fig. 2. XRD patterns of (a) $\mathrm{MgO}$, (b1) $\mathrm{H}_{3} \mathrm{BO}_{3}$, (b2) $\mathrm{B}_{2} \mathrm{O}_{3}$
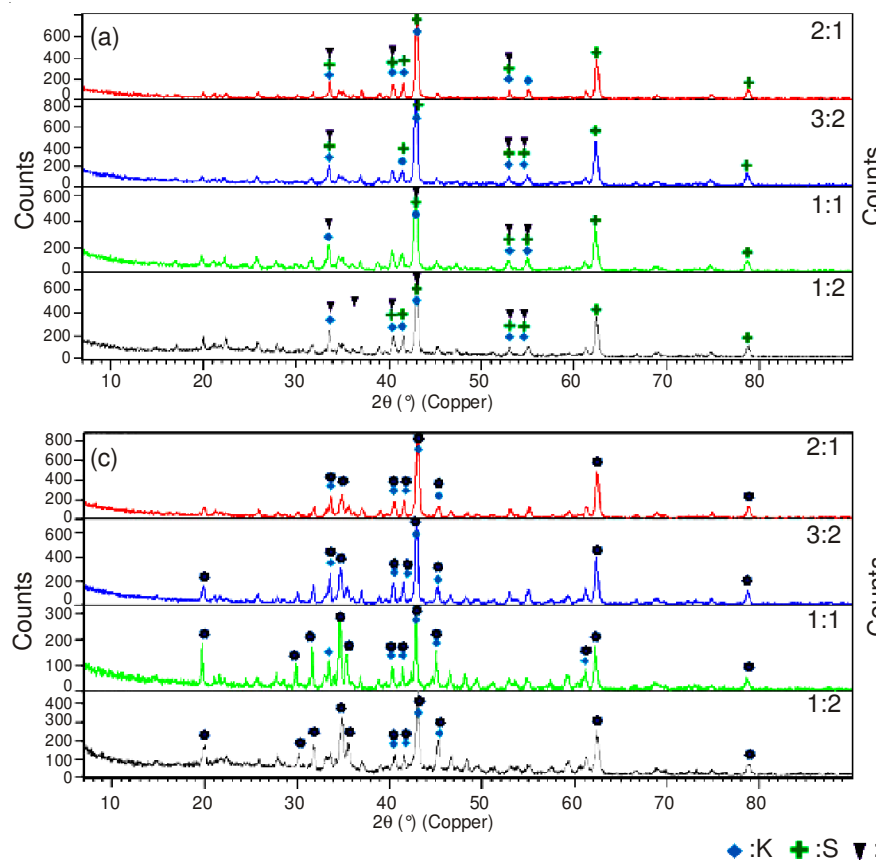

Fig. 3. XRD patterns of synthesized products (a) $900{ }^{\circ} \mathrm{C}-60 \mathrm{~min}$, (b) $900{ }^{\circ} \mathrm{C}-240 \mathrm{~min}$, (c) $1000{ }^{\circ} \mathrm{C}-60 \mathrm{~min}$ and (d) $1000{ }^{\circ} \mathrm{C}-240 \mathrm{~min}$
Characterization results of synthesized magnesium borate minerals: XRD results of synthesized magnesium borates and scores of these minerals are given in Table-1. At the end of the XRD analysis, Kotoite (K) "01-075-1807, $\mathrm{Mg}_{3}\left(\mathrm{BO}_{3}\right)_{2}$ ", Suanite (S) "01-086-0531, $\mathrm{Mg}_{2}\left(\mathrm{~B}_{2} \mathrm{O}_{5}\right)$ " and the other forms of magnesium borates $\left(\mathrm{MgB}^{1}\right)$ "00-031-0787, $\mathrm{MgB}_{4} \mathrm{O}_{7}$ " and $\left(\mathrm{MgB}^{2}\right)$ "01-073-2232, $\mathrm{M}_{2} \mathrm{~B}_{2} \mathrm{O}_{5}$ " were identified. Phase changes with the varying parameter are given in Fig. 3.

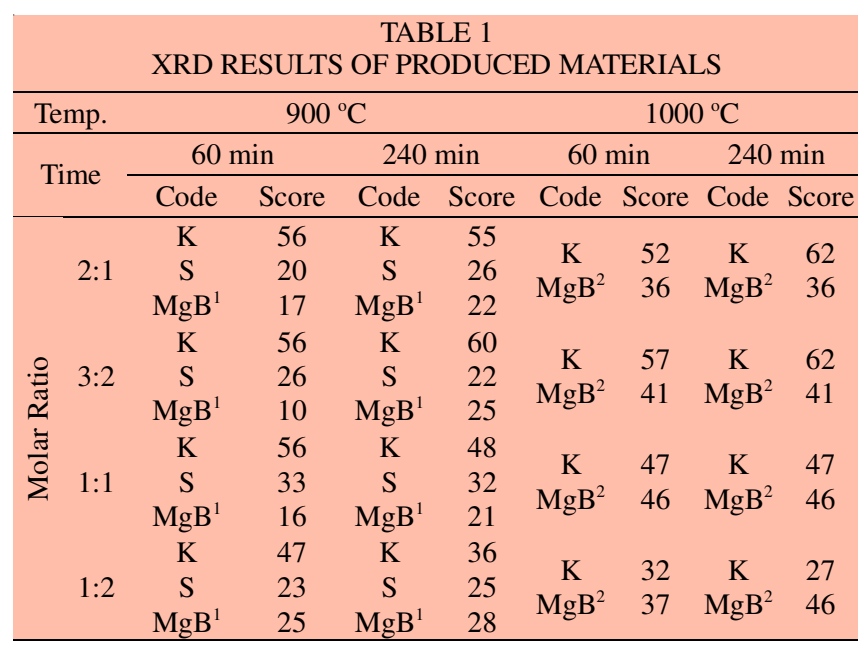

Effects of changing parameters to XRD scores can be seen in Table-1 and the crystallographic data obtained from XRD are given in Table-2. For the experiments made to investigate the change of reaction temperature, the XRD scores of synthesized products increased with increasing temperature where a perfect crystal score is equal to 100 . For the experiments in which the reaction time changed, the XRD scores of synthesized products increased with extended time. According to XRD scores in the scan of the molar ratio of raw materials, it can be said that the most suitable molar ratios values are $3: 2$
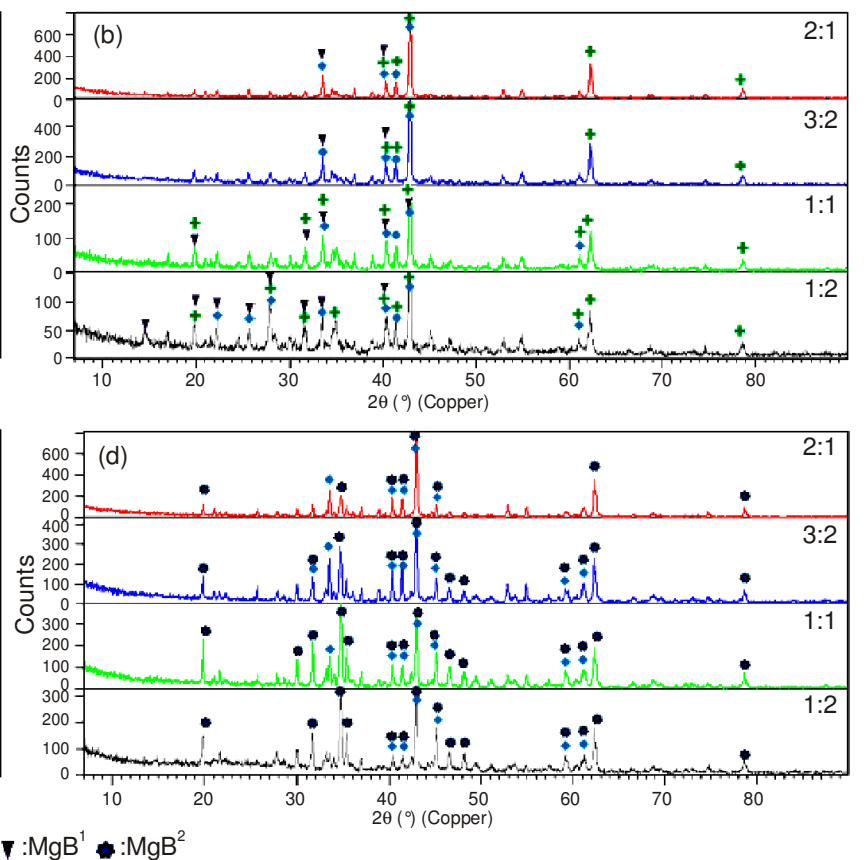


\begin{tabular}{|c|c|c|c|c|}
\hline \multicolumn{5}{|c|}{$\begin{array}{c}\text { TABLE-2 } \\
\text { CRYSTALLOGRAPHIC DATA OF SYNTHESIZED } \\
\text { DEHYDRATED MAGNESIUM BORATES }\end{array}$} \\
\hline $\begin{array}{l}\text { Mineral } \\
\text { name }\end{array}$ & Kotoite & Suanite & $\begin{array}{l}\text { Magnesium } \\
\text { borate }\end{array}$ & $\begin{array}{l}\text { Magnesium } \\
\text { borate }\end{array}$ \\
\hline PDF no. & 01-075-1807 & $01-056-0531$ & 00-031-0787 & 01-073-2232 \\
\hline $\begin{array}{l}\text { Chemical } \\
\text { formula }\end{array}$ & $\mathrm{Mg}_{3}\left(\mathrm{BO}_{3}\right)_{2}$ & $\mathrm{Mg}_{2}\left(\mathrm{~B}_{2} \mathrm{O}_{5}\right)$ & $\mathrm{MgB}_{4} \mathrm{O}_{7}$ & $\mathrm{Mg}_{2} \mathrm{~B}_{2} \mathrm{O}_{5}$ \\
\hline $\begin{array}{l}\text { Molecular } \\
\text { weight } \\
(\mathrm{g} / \mathrm{mol})\end{array}$ & 190.53 & 150.23 & 179.54 & 150.23 \\
\hline $\begin{array}{l}\text { Crystal } \\
\text { system }\end{array}$ & Orthorhombic & Monoclinic & Orthorhombic & Anorthic \\
\hline Space group & Pnmn & $\mathrm{P} 21 / \mathrm{c}$ & Pbca & P-1 \\
\hline $\mathrm{a}(\AA \stackrel{\circ}{)}$ & 5.398 & 9.1970 & 5.896 & 6.187 \\
\hline $\mathrm{b}(\AA)$ & 8.416 & 3.1228 & 13.729 & 9.219 \\
\hline c $(\AA)$ & 4.497 & 12.3030 & 7.956 & 3.119 \\
\hline$\alpha\left({ }^{\circ}\right)$ & 90.00 & 90.00 & 90.00 & 90.40 \\
\hline$\beta\left({ }^{\circ}\right)$ & 90.00 & 104.26 & 90.00 & 92.13 \\
\hline$\gamma\left({ }^{\circ}\right)$ & 90.00 & 90.00 & 90.00 & 104.32 \\
\hline $\mathrm{z}$ & 2.00 & 4.00 & 8.00 & 2.00 \\
\hline $\begin{array}{l}\text { Density } \\
\left(\mathrm{g} \mathrm{cm}^{-3}\right)\end{array}$ & 3.10 & 2.91 & 2.54 & 2.90 \\
\hline
\end{tabular}

and $1: 1$. When $\mathrm{MgO} / \mathrm{H}_{3} \mathrm{BO}_{3}$ ratios are 3:2 and $1: 1$, Kotoite and $\mathrm{MgB}^{2}$ are major components.

Since the molar ratios of 3:2 and 1:1 selected because of their high XRD crystal scores, FT-IR and Raman spectrum are given in Figs. 4 to 7.

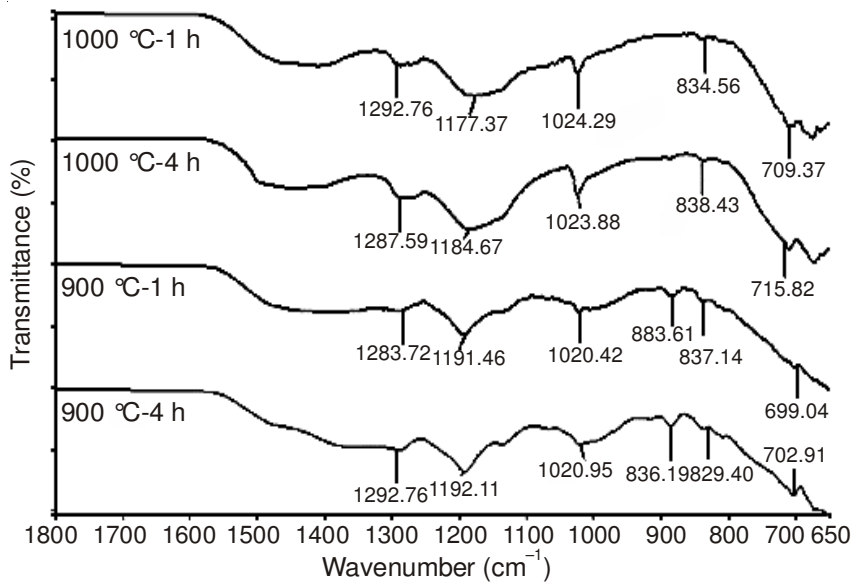

Fig. 4. FT-IR spectra of product for $\mathrm{MgO}: \mathrm{H}_{3} \mathrm{BO}_{3}$ ratio of 3:2 at different reaction temperatures and times

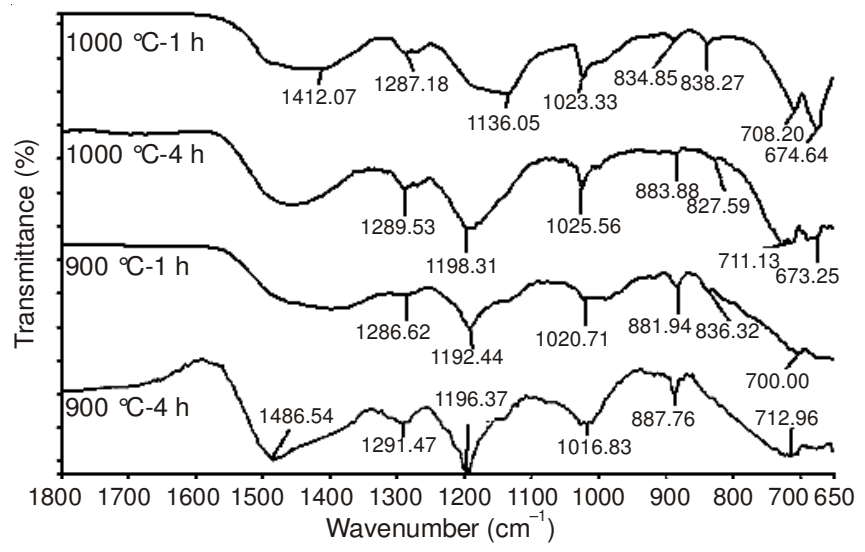

Fig. 5. FT-IR spectra of product for $\mathrm{MgO}: \mathrm{H}_{3} \mathrm{BO}_{3}$ ratio of $1: 1$ at different reaction temperatures and times

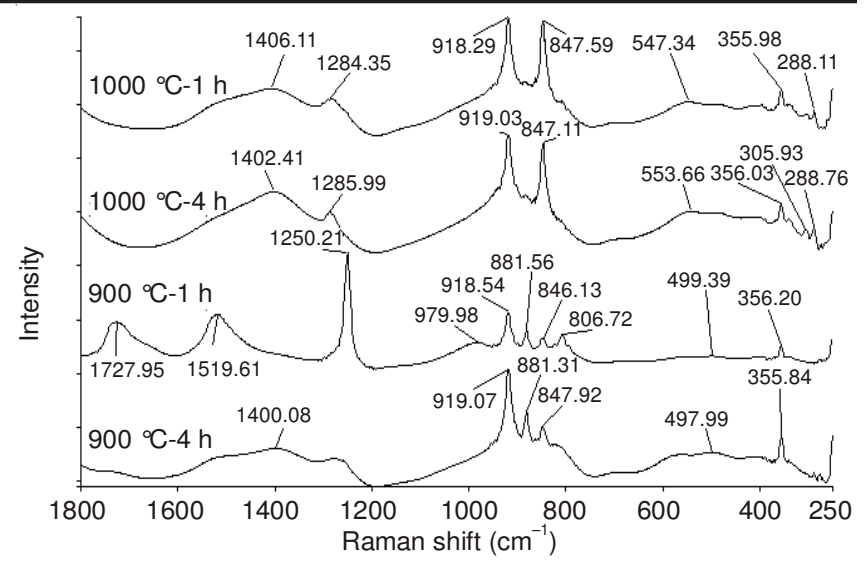

Fig. 6. Raman spectra of product for $\mathrm{MgO}: \mathrm{H}_{3} \mathrm{BO}_{3}$ ratio of 3:2 at different reaction temperatures and times

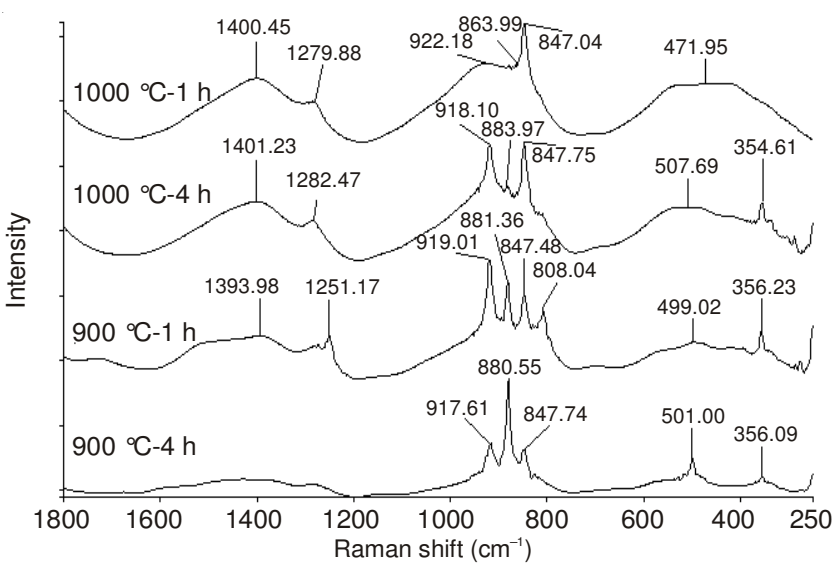

Fig. 7. Raman spectra of product for $\mathrm{MgO}: \mathrm{H}_{3} \mathrm{BO}_{3}$ ratio of $1: 1$ at different reaction temperatures and times

In the FT-IR spectra of synthesized magnesium borate minerals, the main characteristic peak values are seen in Figs. 4 and 5. According to FT-IR spectra, asymmetric stretching of $\mathrm{B}_{(3)} \mathrm{O}$ can cause the first two peaks of the synthesized minerals with the band values between 1486.54 and $1283.72 \mathrm{~cm}^{-1}$. With the band values between 1198.31 and $1016.83 \mathrm{~cm}^{-1}$, peak 3 and 4 may arise from the asymmetric stretching of $\mathrm{B}_{(4)}-\mathrm{O}$ in the structure of magnesium borates. Peak 5 and 6 which had band values changing between 887.76 and $827.9 \mathrm{~cm}^{-1}$, can be explained with the symmetric stretching of $\mathrm{B}_{(3)}-\mathrm{O}$. At the end of the spectrum, last peaks between 715.82 and $673.25 \mathrm{~cm}^{-1}$, peaks 7 and 8 , are results of the bending of three coordinate boron bands.

According to Raman spectra, asymmetric stretching of $\mathrm{B}_{(3)} \mathrm{O}$ might cause first two peaks of produced magnesium borate minerals, with band values between 1727.95 and $1250.21 \mathrm{~cm}^{-1}$. Third and fourth peaks of these products, which are in between 979.98 and $806.72 \mathrm{~cm}^{-1}$, are due to the symmetric stretching of $\mathrm{B}_{(3)}-\mathrm{O}$. Last peaks with the band values below $800 \mathrm{~cm}^{-1}$ are based on symmetric stretching of $\mathrm{B}_{(4)}-\mathrm{O}$.

According to the identification and characterization results of products, 3:2 and 1:1 molar ratios and 240 min of reaction time are ideal for synthesis due to higher XRD scores. Thus, SEM analysis was applied to these products for varying temperatures. Surface images of synthesized materials are shown in Fig. 8. According to Fig. 8 for the molar ratio of 3:2 and $1: 1$ with a magnification of $5000 x$, a great percentage of 


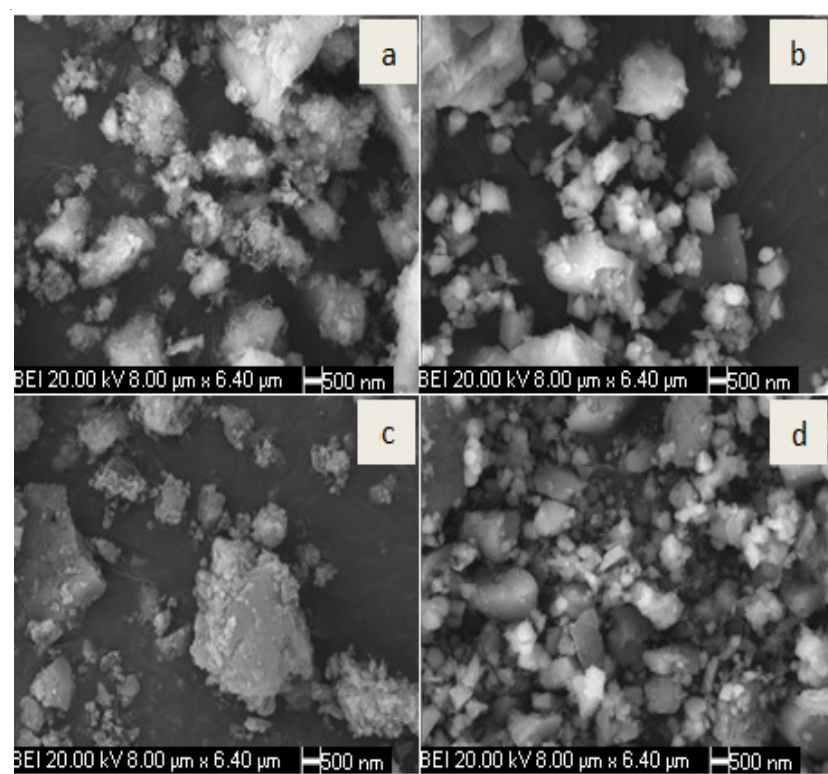

Fig. 8. SEM images of products synthesized at the parameters of $\mathrm{MgO}: \mathrm{H}_{3} \mathrm{BO}_{3}$ ratio; (a) $900{ }^{\circ} \mathrm{C}-3: 2$, (b) $1000{ }^{\circ} \mathrm{C}-3: 2$, (c) $900{ }^{\circ} \mathrm{C}-1: 1$, (d) $1000{ }^{\circ} \mathrm{C}-1: 1$

magnesium borate minerals were crystallized in rectangular shapes. In addition, the synthesized crystals become smaller with the increasing temperature. Particle sizes of the crystals of synthesized materials were found approximately between $585 \mathrm{~nm}$ to $1.6 \mu \mathrm{m}$.

The boron oxide contents of synthesized materials are seen in Table-3. In literature, the boron content of Kotoite and Suanite are 36.54 and $46.34 \%$, respectively ${ }^{16}$. Boron oxide contents of the synthesized materials were changed between $25.46 \pm 0.27$ and $52.86 \pm 0.27 \%$. Higher boron contents of the products can be explained with the excess boric acid at the molar ratio of 1:2. In similar way, lower boron contents of the products can be explained with the excess magnesium oxide and insufficient conversion to magnesium borate structure at the molar ratio of $2: 1$.

TABLE-3

BORON OXIDE CONTENT OF SYNTHESIZED MATERIALS

\begin{tabular}{|c|c|c|c|c|c|}
\hline \multirow{5}{*}{ 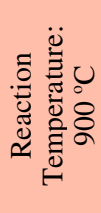 } & $\begin{array}{l}\text { Molar } \\
\text { Ratio }\end{array}$ & $\mathrm{B}_{2} \mathrm{O}_{3} \%$ & \multirow{5}{*}{ 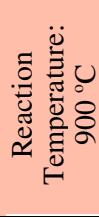 } & $\begin{array}{l}\text { Molar } \\
\text { Ratio }\end{array}$ & $\mathrm{B}_{2} \mathrm{O}_{3} \%$ \\
\hline & $2: 1$ & $38.97 \pm 0.14$ & & $2: 1$ & $25.46 \pm 0.27$ \\
\hline & $3: 2$ & $40.42 \pm 0.82$ & & $3: 2$ & $28.67 \pm 0.41$ \\
\hline & $1: 1$ & $47.13 \pm 0.14$ & & $1: 1$ & $30.80 \pm 0.69$ \\
\hline & $1: 2$ & $52.86 \pm 0.27$ & & $1: 2$ & $33.43 \pm 0.27$ \\
\hline
\end{tabular}

Neutron permeability: Neutron permeability decreases with increasing thickness of the material ${ }^{15}$. Neutron permeability and macroscopic cross section values of the synthesized magnesium borate minerals are given in Table-4. According to the results for each thickness ratio of $\mathrm{I} / \mathrm{I}_{\mathrm{o}}$ was higher at the molar ratio for $1: 1$. The lowest values of total macroscopic cross section and neutron permeation were found for a molar ratio of 3:2. Thus means that synthesized magnesium borate minerals with a molar ratio of 3:2 is more suitable for neutron shielding.

In the experiments, it is seen that thicknesses in materials and molar ratio are important for neutron permeability properties

\begin{tabular}{cccc}
\multicolumn{4}{c}{ TABLE-4 } \\
NEUTRON PERMEABILITY VALUES \\
OF SYNTHESIZED MINERALS \\
\hline Molar ratio & Thickness $(\mathrm{cm})$ & $\mathrm{I}_{\mathrm{o}}$ & $\Sigma_{\mathrm{t}}\left(\mathrm{cm}^{-1}\right)$ \\
\hline \multirow{3}{*}{$3: 2$} & 0.55 & 0.6469 & \\
& 0.75 & 0.6187 & 0.3728 \\
& 1.25 & 0.5500 & \\
\hline \multirow{3}{*}{$1: 1$} & 0.55 & 0.7375 & \\
& 0.75 & 0.7156 & 0.4181 \\
\hline
\end{tabular}

of products. In addition to the effect of thickness, neutron permeation decreased with increasing molar ratio of raw materials in products.

\section{Conclusion}

Boron minerals are used as additive compounds in shielding materials. There is not study in literature on shielding properties of magnesium borate minerals, although neutron and $\gamma$-permeability is known as a feature of boron. In literature, no study is reported about the crystal scores effects of the synthesized materials' neutron permeabilities. In this study, the aim was to determine the neutron permeability of non-hydrated magnesium borate and the effect of XRD crystal scores on shielding features.

In first stage, the influence of thermal production process parameters on synthesis, characterization and crystal structure of materials were studied by the techniques of XRD, FT-IR, Raman and SEM. The investigated parameters were reaction time and molar ratio of the raw materials.

According to XRD scores, crystallinity features were found to change with molar ratio. In all reaction temperatures, the highest XRD scores were obtained for molar ratios of 3:2 and 1:1. Experiments at $900{ }^{\circ} \mathrm{C}$ showed that the production process needed higher temperatures. With increasing reaction temperature from 900 to $1000{ }^{\circ} \mathrm{C}$, higher XRD scores were determined for synthesized materials. In a similar way, a suitable reaction time could be decided as $240 \mathrm{~min}$. According to the identification and characterization results of products, the products which have the highest XRD scores was synthesized at a reaction temperature of $1000{ }^{\circ} \mathrm{C}$, reaction time of 240 min and molar ratios of 3:2-1:1. In these products, Kotoite $\left[\mathrm{Mg}_{3}\left(\mathrm{BO}_{3}\right)_{2}\right]$ and $\mathrm{MgB}^{2}\left(\mathrm{MgB}_{4} \mathrm{O}_{7}\right)$ were the major phases in the products which synthesized at the ratio of $\mathrm{MgO}: \mathrm{H}_{3} \mathrm{BO}_{3}$ $3: 2$ and 1:1, respectively. FT-IR and Raman results of products showed that the peaks of synthesized materials were suitable with the characteristic peaks of non-hydrate boron minerals in literature ${ }^{6,15,17}$. The characters of synthesized material were less affected from changing of experimental parameters.

From the surface morphology of the synthesized materials, it was seen that particles were shaped more rectangular and smaller with increasing temperature. According to the measurements made by SEM, particle sizes were changed between $586 \mathrm{~nm} 1.6 \mu \mathrm{m}$.

Neutron permeability results of the chosen products (at $1000{ }^{\circ} \mathrm{C}$ reaction temperature, 240 min reaction time and 3:21:1 molar ratios) showed that the ratio of $\mathrm{I} / \mathrm{I}_{\mathrm{o}}$ changed with thickness and molar ratio of raw materials in the synthesis process. When thickness of the material was higher, the neutron 
permeability became lower. In a similar way, total macroscopic cross section decreased with increasing material thickness. Although it does not have a tremendous impact, increase on molar ratio of $\mathrm{MgO} / \mathrm{H}_{3} \mathrm{BO}_{3}$, which was a major factor for the structure of the product had a positive effect on neutron permeability of product.

Since the XRD crystal scores of the boron source contributed to the shielding properties, XRD crystal scores are important. In conclusion, the optimum parameters for the synthesis of non-hydrated magnesium borate minerals were determined for the use in neutron shielding purpose.

\section{ACKNOWLEDGEMENTS}

The authors expressed their deepest gratitude and appreciation to Dr. Ekin Kipcak for her valuable help.

\section{REFERENCES}

1. T.R. Prime Ministry SPO, Chemical Industry Private Expertise Commission, Boron Operations Group Report: Ninth Development Plan (20072013), Turkey (2006).

2. U. Dosler, M.M. Krzmanc and D. Suvorov, J. Eur. Ceram. Soc., 30, 413 (2010)
3. X. Tao and X. Li, Nano Lett., 8, 505 (2008).

4. Y. Zeng, H. Yang, W. Fu, L. Qiao, L. Chang, J. Chen, H. Zhu, M. Li and G. Zou, Mater. Res. Bull., 43, 2239 (2008).

5. W. Zhu, G. Li, Q. Zhang, L. Xiang and Z. Zhu, Powder Technol., 203, 265 (2010).

6. L. Zhihong and H. Mancheng, Thermochim. Acta, 403, 181 (2003).

7. E.M. Elssfah, A. Elsanousi, J. Zhang, H.S. Song and C. Tang, Mater. Lett., 61, 4358 (2007).

8. A.S. Kipcak, F.T. Senberber, E.M. Derun and S. Piskin, CEAM, Barcelona, 14-28 November (2011).

9. T. Korkut, A. Karabulut, G. Budak and H. Korkut, J. Radioanal. Nucl. Chem., 286, 61 (2010).

10. S.I. Buiyan and F.U. Ahmet, Health Phys., 57, 819 (1989).

11. S.E. Gwaily, M.M. Badawy, H.H. Hassan and M. Madani, Polym. Test., 21, 129 (2002).

12. M. Adib and M. Kilany, Radiat. Phys. Chem., 66, 81 (2003).

13. N. Singh, K.J. Singh, K. Singh and H. Singh, Nucl. Instrum. Methods, 225, 305 (2004).

14. E.M. Derun and A.S. Kipcak, J. Radioanal. Nucl. Chem., 292, 871 (2012).

15. A.S. Kipcak, P. Gurses, E.M. Derun, N. Tugrul and S. Piskin, Energy Convers. Manage., 72, 39 (2013).

16. J.W. Anthony, R.A. Bideaux, K.W. Bladh and M.C. Nichols, Handbook of Mineralogy, Mineralogical Society of America, Chantilly, VA 20151-1110, USA.

17. J. Yongzhong, G. Shiyang, X. Shuping and L. Jun, Spectrochim. Acta A, 56, 1291 (2000). 